\title{
NARRATIVAS DEL YO Y MEMORIAS TRAUMÁTICAS
}

\author{
Leonor Arfuch ${ }^{*}$
}

\section{Resumen}

Este texto fue presentado como conferencia en la mesa redonda Historia y Narrativas en el Primer Seminario Internacional Historia del Tiempo Presente, impulsado por el Programa de Posgrado en Historia de la UDESC y ANPUH-Santa Catarina, llevado a cabo entre los días 7 y 9 de noviembre de 2011, en Florianópolis/SC. En él, se problematiza el sujeto y su habla, se evidencia el testimonio como narrativa y las diferentes formas en las que la experiencia traumática se traduce en narrativas del yo.

Palabras clave: Narrativas del yo. Recuerdos traumáticos. Historia del tiempo presente.

Quizá como nunca antes, las narrativas del yo invaden el dilatado horizonte cultural contemporáneo. Biografías, autobiografías, autoficciones, diarios íntimos, correspondencias, testimonios, entrevistas, filmes, instalaciones, blogs, chats, fotologs... interminable sería la enumeración de los géneros, formatos y soportes en los que se plasma esa figura elusiva que la marca gramatical cobija sólo temporariamente - y a menudo engañosamente - en el torrente de la discursividad social. Rostros, voces, cuerpos, se hacen cargo de palabras, sostienen autorías, reafirman posiciones de agencia o de autoridad, testimonian el haber vivido o haber visto, desnudan sus emociones, rubrican una política de identidad. Un concierto -o desconcierto- de voces que pueblan de atisbos biográficos toda suerte de discursos, infringiendo los límites, nunca nítidos, entre público y privado.

Hace años se habló de un “retorno del sujeto”, festejado en el marco de la posmodernidad y percibido - desde otra orilla- como el ocaso de la cultura pública y de la primacía de lo social. El tiempo transcurrido fue afirmando ese protagonismo - no desligado sin embargo de otras ideas de socialidad- tanto en el horizonte mediático como en la

\footnotetext{
* Professora da Faculdade de Ciências Sociais da Universidade de Buenos Aires (UBA). E-mail: larfuch@yahoo.com.ar
} 
investigación académica y la experimentación artística. Un fenómeno susceptible de ser definido como ampliación de los límites - o sin límites - del “espacio biográfico”, según mi definición (ARFUCH, 2002), como "giro subjetivo” (SARLO, 2005), o como efecto tardío de aquellas transformaciones de la intimidad (GIDDENS, 1996) que llevaran a hablar sin eufemismos de una (nueva) ‘intimidad pública’ (BERLANT, 1998).

Sin embargo, este subjetivismo a menudo en exceso - donde también podría incluirse la autoayuda - no hace del sujeto - de la multiplicidad de los sujetos - el centro de la escena. Por el contrario, en la era del ‘capitalismo metafísico’ (LASH, 2005) la instancia que regula los destinos del mundo globalizado se presenta sin faz reconocible, sin sujeto, como fuerza ciega que gobierna definiendo las tendencias que se imponen a sus propios ejecutores al frente de gobiernos, regiones, organismos internacionales, donde la tensión entre la política - como ejercicio de administración - y lo político - como pugna agonística por la hegemonía y la decisión- se dirime, las más de las veces, en favor de la primera (RANCIÈRE, 1996; MOUFFE, 2007).

Quizá sea precisamente en contrapunto con esa fuerza ciega - y su entropía- que haya que leer la emergencia abrumadora de la subjetividad, esos pequeños relatos que algunos contraponen a los "grandes relatos" de la modernidad. Pequeños relatos que podemos escuchar, aún en el silencio de la escritura, tanto en trazos biográficos, familiares, como en el testimonio que da cuenta de una memoria traumática, compartida; en la historia de vida que se ofrece al investigador como rasgo emblemático de lo social; en las artes visuales y sus instalaciones de objetos íntimos, cotidianos o en las imágenes del sufrimiento que los medios han convertido en registro paradigmático de la época.

Podrá objetarse que esta enumeración heteróclita no hace justicia a la diferencia valorativa entre los géneros - el testimonio o la historia de vida frente al sensacionalismo mediático por ejemplo, o la experimentación literaria y artística frente a la explosión de intimidad en la Web - pero lo que nos interesa aquí no es tanto la distinción jerárquica de esas formas - sin desdeñar la pertinencia de tal empresa - como sus parecidos de familia, su insistencia, su simultaneidad, el papel decisivo que juegan en la reconfiguración de la subjetividad contemporánea, leída en clave sintomática.

En la tonalidad que caracteriza a este espacio discursivo - tomado el discurso en la amplia acepción de Wittgenstein (1977), como palabra, imagen, gesto, forma de vida - tiene sin duda primacía el valor biográfico (BAJTÍN, 1982), que "no sólo puede organizar una narración sobre la vida del otro sino que también ordena la vivencia de la vida misma y la narración de la propia vida de uno; este valor puede ser la forma de comprensión, visión y 
expresión de la vida propia” (BAJTÍN, 1982, p.136). Varios aspectos merecen destacarse en este concepto, quizá el que mejor explica la predominancia de lo biográfico en la sociedad contemporánea. En primer lugar, su carácter intersubjetivo, la posibilidad de alentar una sintonía valorativa entre el narrador y su destinatario, tanto respecto de la experiencia - la “vida propia” - como de la "vivencia de la vida misma”, es decir, la dimensión ética de la vida en general. En segundo lugar, su cualidad de forma, una puesta en forma - narrativa, expresiva - que es también una puesta en sentido, una “forma de comprensión”. Los valores biográficos son entonces comunes, compartidos entre la vida y el arte, pueden definir los actos prácticos, “son forma y valores de la estética de la vida” (BAJTíN, 1982, p.136). (Cursiva en el original)

Siguiendo esta idea, y en tanto el relato de una vida compromete siempre la temporalidad, hay también, en el espacio biográfico, lo que podríamos llamar el valor memorial, que trae al presente narrativo la rememoración de un pasado, con su carga simbólica y menudo traumática en la experiencia individual y/o colectiva. Un valor doblemente significativo cuando el relato biográfico está centrado justamente en ese pasado por su cualidad misma, por lo que ha dejado como marca, como huella imborrable en una existencia.

Si en toda sociedad la rememoración forma parte obligada de las operaciones de transmisión de la cultura, del trazado de la historia y la ‘invención de la tradición’, es a partir del hito paradigmático de Auschwitz, la Shoá, que la cuestión de la memoria, como dilema y como elaboración ineludible - teórica, ética, política - de las atrocidades del siglo XX y su más allá, se ha transformado en uno de los registros prioritarios de la actualidad, sobre todo en relación con lo que ha dado en llamarse "historia reciente" - o "historia del tiempo presente", como en el evento que nos convoca. Inflación memorial, según algunos, por cuanto no solamente se despliegan, en una temporalidad diferida, innumerables narrativas - recuerdos, testimonios, experiencias, autobiografías, (auto)ficciones, todo tipo de material documental, visual y artístico - sino también, y en estrecha relación, las políticas oficiales de la memoria: museos, memoriales, monumentos, contra-monumentos, efemérides, conmemoraciones... una maquinaria material y simbólica que puede tornarse en un 'abuso de la memoria’, según la conocida expresión de Todorov (2000).

Pero no es solamente la inquietud del pasado la que atormenta la memoria - y sus obligados “usos del olvido” (YERUSHALMI, 1989). Es también su reviviscencia en el presente bajo la forma de guerra perpetua que sólo va cambiando de lugar - lejanas y cercanas 
geografías-, haciendo de la categoría de víctima, allí y aquí, un personaje recurrente, difuminado en cifras abstractas y no por ello menos aterradoras.

Si el auge actual del testimonio apunta a la elaboración de las experiencias traumáticas de décadas pasadas, rodeando de palabra lo indecible - hay, como es sabido, temporalidades de la memoria, cosas que sólo pueden aflorar paulatinamente, a medida que pasan los años y la distancia atenúa la angustia, libera el secreto o la prohibición - es la fotografía la que parece tomar a su cargo el sufrimiento mudo del presente que padecen poblaciones enteras, sea en el ojo del reportero gráfico o del artista - o en su cada vez más frecuente confluencia ${ }^{1}$ haciendo de las imágenes una narrativa a la que para siempre faltará la singularidad biográfica. Relatos contra imágenes - desgarradoras - cuya proliferación mediática plantea no pocos dilemas éticos y estéticos.

Lo que me propongo analizar aquí es justamente la relación entre el valor biográfico y el valor memorial. El modo en que se articulan, en narrativas que escapan a cánones estrictos, autobiografía, memoria y testimonio. Narrativas de mujeres, en este caso, llevadas a dar cuenta de las experiencias traumáticas que padecieron bajo la última dictadura militar en Argentina (1976-1983), más allá de la declaración ante la justicia como testigos para el procesamiento de los represores. Más allá, en una doble temporalidad: la de la cronología veinte años después-, la de la escritura, cuya marca no sólo excede el momento de su inscripción sino que se despliega, anticipatoriamente, hacia cada lectura. Esa escritura es precisamente el foco de mi atención: no tanto el relato de los "hechos" como los modos de su enunciación, el trabajo del lenguaje que impone una forma a la experiencia - y no meramente viene a representarla - los avatares del discurso según las figuras tropológicas de la narración. Esta postura analítica no supone el desmerecimiento de lo dicho, su carácter de prueba, una vez más, de los crímenes de lesa humanidad cometidos - secuestro, tortura, confinamiento, asesinato, desaparición - su innegable - y necesaria - dimensión ética. Tampoco se pone a resguardo del impacto emocional, de la conmoción que este tipo de relato genera. Intenta más bien percibir, en la dinámica misma del narrar, la trama sutil en que se entretejen lo personal y lo colectivo, el carácter elusivo de aquello que se quiere nombrar y definir, en definitiva, la posibilidad y la imposibilidad de la transmisión, de dar cuenta de la (propia) experiencia.

\footnotetext{
${ }^{1}$ Como ejemplos de esta modalidad creciente se puede mencionar al artista chileno Alfredo Jaar, que viene desarrollando su arte conceptual, donde la fotografía es determinante, en territorios en conflicto - Ruanda, Palestina - y, del otro lado, el reportero gráfico francés Luc Dalahaye, que, desde esos mismos territorios - Irak, Bosnia, Rusia - fue haciendo cada vez más de su métier un arte reconocido como tal. Ver al respecto DIDIHUBERMAN y otros, 2008.
} 


\section{El testimonio como conversación}

Para acoger un testimonio éste deber ser apropiado, es decir, despojado, en la medida de lo posible, de la extrañeza absoluta que engendra el horror. Marc Bloch

De un corpus bastante amplio, que ofrece ciertas similitudes ${ }^{2}$, me interesó en particular Ese Infierno. Conversaciones de cinco mujeres sobrevivientes de la ESMA ([1998] 2006) $)^{3}$ un libro publicado con la co-autoría de Munú Actis, Cristina Aldini, Liliana Gardella, Miriam Lewin y Elisa Tokar, donde la conversación sostenida en diversos encuentros, fuera de toda instancia declaratoria, intenta (re)construir, desde los distintos yoes, una memoria compartida.

El testimonio como conversación, tal podría ser un título hipotético para este libro. Que por un lado reafirma una vez más el carácter terapéutico, socializante y revelador de nuestra más conspicua práctica comunicativa, por el otro introduce la ligereza del habla coloquial, la dinámica fluctuante de voces que se superponen e interponen, los giros familiares, las expresiones de la vida cotidiana, en otro modo del decir que se sitúa muy lejos de ella. Dos géneros casi contrapuestos, cuya confluencia da como resultado una forma-otra, una aleación que no deja de ser problemática. No porque el fluir de las voces pueda traer consigo rasgos de humor o alentar el optimismo en los momentos más densos - esta sería justamente su función terapéutica - sino por la divergencia de tonos y estilos, por la distancia entre lo dicho y el decir, entre la minucia de la cotidianidad del campo y sus anécdotas y lo ominoso del ámbito que las contiene, entre el horror de Ese infierno en todo su detalle, el tormento de cuerpos y almas, y el devenir sin escollos de la conversación - convenientemente editada -, sin rastros de silencios, vacilaciones, apagamientos de la voz... ${ }^{4}$ Un esforzado recordar, un decir “todo”, en un flujo continuo de palabra que parece no querer dejar ningún resto y que precisamente por eso podría ser leído como síntoma.

\footnotetext{
${ }^{2}$ Varias de estas obras asumieron un carácter colectivo: Marta Diana, Mujeres guerrilleras .Sus testimonios en la militancia de los setenta (1996), compilación de entrevistas realizadas por la autora; Noemí Ciollaro, Pájaros sin luz, Testimonios de mujeres de desaparecidos (1999), también una compilación de entrevistas; Nosotras, presas políticas. 1974-1983 (2006), recopilación de relatos, cartas, poemas y dibujos hecha por las mismas protagonistas. En el género poético, Susana Romano Sued aborda su experiencia concentracionaria en Procedimiento. Memoria de La Perla y La Rivera (2007).

${ }^{3}$ Curiosamente, ambas obras tienen los mismos pies de edición: la primera en 1998, poco después de los veinte años del golpe, la segunda en la efemérides de los treinta años (2006).

${ }^{4}$ Las narradoras refieren en su prólogo a los silencios, interrupciones, llantos, que muchas veces las acometieron. Su borradura en la versión final - una opción entre otras posibles- es significativa para un análisis de discurso.
} 
Porque si es verdad que, como afirma la teoría, el trauma está más allá del lenguaje y al mismo tiempo necesitado de él, quizá sea justamente el lenguaje - ¿qué lenguaje? - el dilema intrínseco del testimonio. Como bien señala Leigh Gilmore (2001, p.7) “Los sobrevivientes del trauma son compelidos a testificar recurrentemente acerca del mismo, en un esfuerzo por crear tanto el lenguaje que pueda manifestarlo y contenerlo como los testigos que puedan reconocerlo” (la traducción es mía). Se trataría entonces de remplazar las manifestaciones a través de las cuales el inconsciente inicialmente "habla" (flashbacks, pesadillas, desbordes emocionales), por un lenguaje consciente que intentará hablar una y otra vez de aquello que no puede ser dicho. Contradicción aparente que entraña una ambivalencia constitutiva: la posibilidad y la imposibilidad del lenguaje para dar cuenta del trauma.

Pero el testimonio requiere, además de un lenguaje, un marco apropiado para su efectuación - jurídico, institucional -, un otro dispuesto a la escucha y a la contención y está sujeto no solo a una fuerte exigencia de veracidad y fiabilidad sino también de legalidad, por cuanto se puede ser acusado por falso testimonio.

En la escena de la conversación construida en la escritura, donde se alternan fluidamente las réplicas de las autoras, confluyen - y se contrarían- rasgos de varios géneros discursivos: el testimonio, la autobiografía, la confesión, en una narrativa plena de recursos literarios - descripciones, temporalidades, escenas y personajes, diálogos en discurso directo, imaginación de situaciones o desenlaces de historias no conocidas, etcétera- que podría definirse como una suerte de autoficción colectiva.

Del lado del testimonio, los dichos, aún por fuera del marco canónico de la declaración ante la justicia, intentan sin embargo ajustarse al principio de veridicción y pueden ser corroborados de inmediato por cuanto remiten a situaciones vividas por todas. Las interlocutoras interrumpen entonces la escucha - testimonial - para convertirse a su vez en testigos en la doble acepción de lo vivido y lo presenciado, distinción que se hace patente en el relato Del lado de la autobiografía, si bien no alcanza a delinearse un relato de la vida de cada una, aparecen fragmentos, anécdotas, sensaciones, rasgos de carácter $\mathrm{y}$, consecuentemente, sintonías vivenciales entre las interlocutoras, "momentos autobiográficos”, al decir de Paul de Man (1984), esa figura de la lectura en la que se produce un alineamiento entre los sujetos involucrados - el narrador, el lector - donde “ambos se determinan mutuamente por una sustitución reflexiva” (MAN, 1984, p.68). Una figura que, según de Man, no es privativa de la autobiografía sino que puede aparecer en cualquier texto y que en este texto opera en una triangulación especular: somos, en tanto lectores, "terceros incluidos" 
en esa conversación, que esboza además una cierta biografía colectiva. ${ }^{5}$ Pero también aparecen, en el vaivén del diálogo, instancias que podríamos llamar "momentos confesionales”, en los cuales algo de lo no dicho - quizá nunca dicho - surge súbitamente y se vuelve a acallar. Aquí puede reconocerse igualmente una experiencia corriente en la conversación cotidiana: lo que aparece sin ser llamado, en la lógica propia del lenguaje, como emergente del inconsciente o porque todavía no tenía una precisa formulación. La escucha se revela una vez más - en la escena de la escritura - como esencial para la constitución subjetiva y por ende, para la vida.

Liliana: Ahora me doy cuenta de que yo, estando adentro, sentía como si me hubieran puesto un vidrio que me separaba del mundo. Sabía que mi nombre no tenía el mismo valor que antes, era un nombre desaparecido.

Elisa: Yo no podría encontrar un término para explicar lo que me pasaba, ni contarlo de esa manera. Mi nombre en la militancia era Mónica. Cuando me llevaron a trabajar en Cancillería ${ }^{6}$ había una compañera que se llamaba así y cuando la gente le decía "Mónica" respondíamos las dos. Yo era Elisa Tokar, pero seguía siendo Mónica, no podía responder a otro nombre que no fuera Mónica.

Liliana: Habrán pensado que estabas loca.

Munú: $Y$ vos explicabas que te decían Moni...

Elisa: Yo les decía que me decían Moni por monigote (risas) (...)

Miriam: Vos identificabas el nombre Moni con la militancia y con el adentro.

Elisa: Claro, yo en Cancillería seguía siendo secuestrada y entonces seguía siendo Moni, respondía a ese nombre. (2006, p. 82)

\section{(...)}

Munú: Para mí esos años son larguísimos. Uno habla de una cosa y de otra y, en medio, parece que hubieran pasado años...Ya que hablamos de identidad, no sé cómo vivieron ustedes, qué les significó, el hecho de que nos pusieran un número y nos identificaran de esa forma.

Miriam: A mí el tema del número en realidad no me molestaba tanto.

\footnotetext{
${ }^{5}$ El concepto de de Man, la idea de una “mutua sustitución reflexiva” entre ambos partícipes de la comunicación - en la lectura pero también en presencia- podría pensarse en cierta vecindad con el concepto de "valor biográfico” de Bajtín (1982), que también compromete una sintonía valorativa.

${ }^{6}$ Algunos detenidos eran llevados a trabajar en reparticiones oficiales, como en este caso.
} 
Elisa: A mí tampoco.

Miriam: Yo era 090.

Elisa: A mí me daba tranquilidad. Era 481 (...) Cuando entraba en Capucha ${ }^{7}$ o cuando salía, o me llevaban a un paseo $^{8}$, decían “481”. A mí me hacía bien eso, yo necesitaba sentir que era una presa. Era una forma de tomar distancia de los oficiales de la Marina.

Munú: La necesidad de la reja.

Elisa: ¡La famosa reja que no teníamos! (2006:83)

El tema de la reja (que sí existía en otros campos) vuelve más adelante:

Elisa: Decía (se refiere a una compañera de otro campo) que la reja cuidaba su salud mental. Hablaba de la reja simbólica que establecía quien era quien. El carcelero era el carcelero.

Munú: Ellos todos el tiempo desvirtuaban la situación. Venían, te molían a palos y a las dos de la mañana te sacaban, te subían a un auto, te llevaban a cenar. Te sentaban a la misma mesa, te convertían en par, comías la misma comida, querían que opinaras, y después, vuelta para Capucha. ¡Esto pone loco a cualquiera! ¡Menos a nosotras! (risas).” (2006: 102)

¿Qué estrategias - de ficcionalización, podríamos decir - se ponen en juego en la autorrepresentación? ¿De qué manera se construyen las posiciones enunciativas? Si bien hay diferencias entre las distintas autoras - énfasis, tonos, estilos - puede reconocerse una línea común, quizá producto del trabajo de edición, pero que traduce una toma de posición compartida. Más allá de la asunción de un yo sin reservas, del amplio despliegue de la subjetividad, es notoria la común obsesión del detalle en el relato de lo padecido, que aparece como insistencia del dato y de la prueba - testifical, testimonial, jurídica- pero también, podría pensarse, de las pruebas que, cual personajes de una épica, han atravesado y superado. Quizá es interesante recordar aquí el concepto de "prueba cualificante”, que A.J. Greimas (1983) elaboró a partir de las funciones del cuento popular según la clásica tipología de Propp (1977): la prueba como paso obligado en el tránsito del héroe (la heroína), con sus adyuvantes y oponentes, hacia la madurez, la sabiduría, el poder o la justicia, corolario obligado de la eterna lucha entre el Bien y el Mal. Algo de esa antigua herencia perdura en el relato de las cinco mujeres, dotándolo de un cierto carácter heroico, quizá no

\footnotetext{
${ }^{7}$ Capucha era uno de los lugares siniestros de la ESMA, donde dormían los presos sobre colchonetas en el piso, encapuchados y con interdicción de palabra.

${ }^{8}$ El "paseo" era una salida que tenía como objeto la posible delación de algún compañero visto en la calle o en algún lugar público, propósito que generaba mucha angustia entre los detenidos y que no siempre se cumplía.
} 
buscado, pero que hace pensar en las múltiples formas que puede asumir la heroicidad, más allá de sus figuras típicas y a menudo trágicas. Han logrado sobrevivir, sobreponerse a la tortura, al sufrimiento físico, psíquico y moral, a la perversidad del trato de los represores, ${ }^{9}$ al miedo y la desesperanza. Han logrado, como dice la expresión popular, "rehacer su vida”, aún penosamente, contrariando el objetivo último del poder concentracionario: el arrasamiento de la subjetividad y de toda dignidad. Pero quizá, en esa acumulación abrumadora de las pruebas que roza el umbral de lo excesivo, pueda leerse, una vez más, lo sintomático, la persistencia de la huella traumática.

Está por cierto la culpa por haber sobrevivido, que se expresa desde el comienzo del libro y que quizá busca equipararse -sin saberlo- con el recuerdo de lo padecido. Está también el compromiso ético de hacer saber, que todos los que atravesaron la experiencia concentracionaria comparten. Pero hay además, en tanto relato de la/s experiencia/s de mujeres, algunos aspectos que vale la pena considerar desde una perspectiva de género.

Es bien reconocido el papel preponderante que ha tenido - y sigue teniendo - la autobiografía de mujeres - y en general, la asunción de la primera persona en relatos de tinte confesional o testimonial - en la configuración del campo epistémico de los diversos feminismos, los estudios de género y de la diferencia sexual, y la redefinición obligada, desde esas perspectivas, de los conceptos de género, identidad, agencia y experiencia. La experiencia traumática, justamente, encuentra en estas formas un modo privilegiado de expresión, en un momento del mundo en el cual, como afirma Leigh Gilmore (2001), en los últimos treinta años parecen coincidir "la era de las memorias (memoir) y la era del trauma”, estimulando una multiplicidad de relatos en las más diversas lenguas y soportes - mediáticos, antropológicos, fílmicos, artísticos - y dando lugar, simultáneamente, a un renovado movimiento de la crítica en torno del sujeto, el lenguaje, la narración y la propia noción de experiencia. Lejos ya de la idea de una "experiencia femenina”, que nos llevaría de retorno al esencialismo, se trataría más bien de pensar las experiencias de las mujeres, con sus semejanzas y diferencias, como producto de lo que podríamos llamar, con Teresa de Lauretis (1992), las “tecnologías del género” es decir, la trama social, semiótica, epistemológica y crítica en la que se construyen sujetos generizados.

\footnotetext{
${ }^{9}$ En la segunda etapa de la vida en el campo, cuando ya estaban incorporadas al “Staff”, es decir, al trabajo esclavo de archivo, lectura y preparación de material para sustentar las ambiciones políticas del jefe de la Armada, más allá de llevarlas a cenar - y alguna vez a bailar -, también solían acompañarlas casas de sus familiares "de visita” y hasta compartir la mesa con ellos, sin que esto redundara en ninguna certeza sobre sus destinos futuros. La siguiente "etapa” consistió en darles a algunas la opción de salida del país, y mantener a otras, siempre bajo amenaza, en libertad vigilada.
} 
Evitando entonces las generalizaciones, parecería que en el detalle de los padecimientos personales que sustenta las estrategias de autorrepresentación de las cinco mujeres, se repite quizás una fórmula que aparece insistentemente en otros ámbitos y escrituras, aunque no necesariamente en relación a la experiencia traumática. La crítica literaria Rita Felski (1989), por ejemplo, señala que muchas mujeres escritoras dentro del feminismo eligen el estilo confesional para producir un auténtico self, eludiendo la teoría y basando la subjetividad en los detalles personales de su experiencia vivida, lo cual resulta, en su opinión, en una posición de enunciación naif. Leigh Gilmore (1994), por el contrario, considera que en el recurso al discurso confesional las mujeres afirman una posición de sujeto que les otorga autoridad para reivindicar su verdad. ${ }^{10}$

En el caso de nuestras narradoras, el testimonio detallado de la experiencia traumática, que parecería ser el motivo inspirador y el objetivo del libro, juega sin embargo un papel diferente al de la declaración ante el tribunal. Allí, se trataba de dar pruebas para el juzgamiento y la condena de los victimarios desde la posición de víctimas. Aquí, de dar prueba desde otro lugar, cuya autoridad se construye justamente en el relato: el de sobrevivientes. Pero este último significante, que aparece enfatizado en el subtítulo del libro, no remite pasivamente a la marca indeleble del pasado - el haber resistido, el haber escapado al poder concentracionario y su distribución arbitraria de la muerte - sino, como vimos, adquiere un sentido activo en el presente: el haberse sobrepuesto a sus efectos devastadores, la voluntad de recordar, la potestad del decir, en síntesis, el asumir un lugar de agencia, ${ }^{11}$ donde se entraman identidad, verdad y poder. Un lugar sostenido por el nombre, de retorno del nom de guerre de la militancia y del número que intentó borrarlo, un nombre marcado por la genealogía, que también se intentó destruir. ${ }^{12}$ Un lugar, además, compartido, donde las voces se refuerzan mutuamente en la reafirmación de los dichos y operan simultáneamente como garantes de verdad.

Este carácter relacional que asume la enunciación, puesto explícitamente en escena, parece dar razón a algunas críticas feministas que consideran que la metonimia, el tropo de contigüidad y relación, es el favorito en la autorrepresentación figurada de las mujeres en la autobiografía - siempre en relación con otros -, a diferencia de los varones, que preferirían la

\footnotetext{
${ }^{10}$ Gilmore presenta esta discusión con Felski en su libro Autobiographics. A feminist theory of women's selfrepresentation. (1994: 225)

${ }^{11}$ La noción de agencia es utilizada por algunas feministas para oponerse a cierta tendencia dentro del feminismo a la victimización de las mujeres como puro objeto de sujeción. Así se puso el acento en la capacidad de acción de las mujeres, sus estrategias de supervivencia, resistencia, negociación, etcétera. Con este concepto las feministas se distancian a su vez de la noción de autonomía del sujeto libre y volitivo.

${ }^{12}$ El nombre no siempre es asumido en los relatos testimoniales de mujeres recogidos fuera de instancias judiciales.
} 
metáfora, el tropo de la sustitución, que opera en el eje asociativo/paradigmático y connota jerarquía e identidad (para Paul de Man, recordemos, la figura de la autobiografía es la prosopopeya). Si esto se tradujera efectivamente en dos modos opuestos de autorrepresentación, reflexiona Gilmore (1994), tal distinción iría más allá de la retórica para adquirir una dimensión política -aunque sabemos que la retórica es política. Política que, en el relato que nos ocupa, se torna también, obligadamente, en una política de la memoria.

Si el cuerpo está tradicionalmente excluido de la autobiografía, volcada más bien hacia estados de alma, intelecto, espíritu, memoria, en este tipo de relatos aparece comprometido de modo prioritario, no sólo como objeto de tormento sino también como un registro importante de autoafirmación. Sin embargo, no es fácil traer al presente narrativo escenas que estremecen de sólo imaginarlas, que ponen en juego ese poder icónico de la palabra que hace ver según los dictados de cada percepción. Escenas, justamente, que son las que dejaron las marcas más traumáticas. Pero si su enunciación es difícil - difícil poner voz y palabra allí donde el lenguaje falta - también es problemático el lugar que le propone a su destinatario, que es llevado de algún modo a mirar como voyeur, a traspasar el umbral de aquello que tal vez no quiera siquiera imaginar. Se juega aquí también el clásico dilema del "ver o no ver" que se ha planteado una y otra vez en relación a la imagen traumática y en particular, a las imágenes aterradoras de los campos de exterminio nazis. Si, como afirma Didi-Huberman (2004) en una ya clásica polémica en torno de “cuatro fotografías arrancadas del infierno” sobre las cuales se atrevió a aventurar un relato, "para saber hay que imaginarse”, el testimonio requiere, casi obligadamente, de la imaginación. Pero ese saber supone no solamente el conocimiento sino una reflexión, una respuesta, una toma de posición ética que vaya más allá del impacto compasivo, revulsivo y hasta admirativo que puede producir el relato del sufrimiento - de cualquier sufrimiento.

Es quizá en ese registro, que convoca lo más crudamente “femenino” - lo sexual, lo carnal, la imaginería que recubre la corporalidad - donde el relato de las autoras tropieza con la mayor dificultad enunciativa: el querer dar testimonio con el realismo del detalle de la prueba jurídica pero fuera del ámbito que le es propio y fuera del género discursivo capaz de sostenerlo.

Y aquí volvemos a la cuestión del lenguaje: el lenguaje no meramente viene a expresar la experiencia sino que se adueña de ella, la configura en el aquí y ahora de la enunciación, ese acontecimiento que, según Benveniste (1971), hace posible la emergencia de un yo, un yo que a su vez instaura - se dirige a - un tú, abriendo así el circuito intersubjetivo de la 
comunicación. Pero ningún yo habla por fuera de un género discursivo y, podríamos agregar, tampoco dice lo mismo en cualquier género.

La autobiografía y el testimonio, por ejemplo, se ajustan - idealmente - a un principio de veridicción que no rige para la novela y otros géneros libres de invención. La conversación cotidiana se distingue de la entrevista periodística por el carácter institucional de esta última, sus partícipes y - a veces - sus temáticas, pero sobre todo por el "contrato de lectura” de veracidad y objetividad que sostiene - también idealmente - el género de la información.

En el caso de las "Conversaciones”, si bien se da la obligada confluencia del testimonio, la autobiografía y la confesión, es el género elegido el que impone su forma a la experiencia traumática. Una interlocución de notoria convivialidad, que tiene incluso sus momentos de "charla de mujeres" con su humor y su trivialidad - y su evidente poder reparador -, pero que no puede eludir esa tensión constitutiva que ya señaláramos: la distancia entre lo dicho y el decir, entre el detalle aterrador propio de este tipo de testimonio y la forma que adopta su enunciación.

Podría pensarse, ante esta disimetría, que fue quizá la conversación el modo apropiado - volviendo a nuestro epígrafe de Bloch - en que pudo aflorar, a lo largo del tiempo, con la contención y la compañía de pares, ese relato colectivo del horror, aligerado de su “extrañeza”. La cuestión es si finalmente se logra ese resultado, si la modalidad elegida lo hace en verdad más soportable o pone en escena una vez más el límite de lo decible, su radical extrañeza. Quizá el discurso diga, alegóricamente, ambas cosas.

Porque la conversación trascripta, editada, pasada a la escritura, pierde su inmediatez, su carácter "primario", se transforma en un género secundario - siguiendo a Bajtín-, más elaborado, producto de un trabajo del lenguaje que opera en distancia de la voz - el énfasis, la entonación, la emoción - en un proceso de pérdida, de entropía. Género, por otra parte, que ya tiene una larga tradición periodística y literaria: los libros de “Conversaciones” con personajes notables, escritores, poetas, filósofos, científicos. Pero allí el diálogo responde más bien al modelo de la entrevista que al de la conversación cotidiana, hay una relación a menudo especular entre entrevistador y entrevistado, hay un personaje que se quiere construir o un retrato que se pretende dibujar. ${ }^{13}$

En estas “Conversaciones” - que quizá podrían pensarse como "fuera de género” - el objeto es bien otro y quizá su ambivalencia - o su extrañeza - dependa en definitiva de los

\footnotetext{
${ }^{13}$ He abordado esta temática en La entrevista, una invención dialógica, (2da. Edición, 2010)
} 
avatares de la recepción. Cumplida ya la catarsis, lejos de la - supuesta - espontaneidad del decir, el libro vuelve a decir, asume el desafío de la visibilidad, de exponer la intimidad más recóndita bajo la luz inquisidora de lo público y en tanto enunciado se dirige a alguien y responde - anticipadamente - a sus interrogantes y a sus expectativas. Tiene sentido aquí, una vez más, la pregunta que surge ante toda escritura, ¿Para quién se escribe, quién es el destinatario al que se intenta responder y del cual el discurso se hace cargo, en términos de responsabilidad ética?

\section{Recapitulaciones}

Si lo biográfico, lo privado y lo íntimo constituyen umbrales hipotéticos hacia la profundidad del yo, una gradación donde lo biográfico puede ser público sin marca de privacidad - el relato de las estaciones obligadas de la vida, el currículum-vitae, la crónica histórica, el panegírico, la necrológica - y lo privado puede hacerse público sin marca de intimidad, lo íntimo también puede prescindir, en ocasiones, de los pasos atemperados de esa gradación, irrumpir en lo público con una violencia de palabra que supera quizá la de la imagen - aunque en verdad la palabra también es imagen. Esa violencia es justamente la del testimonio en el desnudamiento traumático de la intimidad sometida a tormento, en el detalle ominoso del agravio a los cuerpos, esa "nuda vida” que se presenta sin contornos biográficos, sin siquiera el cobijo de la privacidad.

Esos testimonios, con su horror fantasmático, su correlato de pesadilla, han venido poblando los tramos sucesivos de la memoria, desde el Nunca Más y el posterior Juicio a las ex juntas militares hasta el presente, en los juicios orales y públicos que siguen teniendo lugar. Pero más allá de los estrados, del marco institucional, esos relatos vuelven a emerger, en una insistencia sintomática según nuestra hipótesis, para poner palabras allí justamente donde tantas voces faltan y el lenguaje falla y la posibilidad de decir de verdad encuentra una vez más su límite. Sin embargo, al ser acogidos en otras narrativas - autobiografías, relatos de vida, entrevistas, cartas, formas híbridas entre ficción y no ficción ${ }^{14}$ - ya no dicen lo mismo. Pueden hablar sin el despojamiento de la prueba jurídica, con la perspectiva de la distancia o el refugio de la interlocución, bajo el amparo de la biografía, el recuerdo feliz, la vida antes o la firmeza de la supervivencia, con el apoyo de la metáfora, la imaginación, el humor o la reflexión política. Y es quizá la literatura ficcional la que ha trabajado con mayor

\footnotetext{
${ }^{14}$ Un ejemplo temprano de esta combinatoria fue sin duda la novela Recuerdo de la muerte, de Miguel Bonasso (1984)
} 
fortuna la forma del decir, la palabra como modo de abrigar la desnudez, de reencontrar la dimensión poética de la existencia.

A su modo, la narrativas que estuvimos analizando también intentan brindar un cobijo al testimonio: el de la convivialidad de la conversación, que se aparta de la fórmula más corriente de la voz testimonial - el relato autorreferencial de las vicisitudes - para asumir una posición polifónica que multiplica las subjetividades.

Esta opción discursiva, en una cercanía vivencial que ilumina momentos y circunstancias que quizá quedarían ocultos en relatos más distanciados, conlleva sin embargo ciertos riesgos: el desborde de la intimidad - en épocas de asedio de intimidad mediática - y el devenir fortuito de la conversación, que puede dejar la impronta de lo cotidiano aun en los momentos más sensibles de una evocación, naturalizando en cierto modo lo que fue una experiencia límite en un estado de excepción.

Podríamos decir entonces que no hay testimonio "puro" fuera del marco de su enunciación, que es el tipo de relato - o el género discursivo - elegido el que lo dota de sentido. Y que el concepto de literatura testimonial, que suele utilizar Hayden White, parece muy apropiado para designar esa miríada de formas posibles en las cuales la experiencia traumática se hace palabra, se obsesiona en detalles, dice más de lo que dice, dejando siempre el resto de lo inexpresable.

\section{NARRATIVAS DO EU E MEMÓRIAS TRAUMÁTICAS}

\section{Resumo}

O presente texto foi apresentado em forma de palestra na mesa redonda Historia e narrativas no I Seminário Internacional História do Tempo Presente, promovido pelo Programa de Pós-Graduação em História da UDESC e ANPUH-Seção SC, realizado nos dias 07 a 09 de novembro de 2011, em Florianópolis/SC. Nele problematiza-se o sujeito e sua fala, evidencia-se o testemunho como narrativa e as muitas formas possíveis nas quais a experiência traumática traduz-se em narrativas do eu.

Palavras-chave: Narrativas do eu. Memórias traumáticas. História do tempo presente. 


\section{NARRATIVES OF SELF AND TRAUMATIC MEMORIES}

This text was presented as a lecture in the History and Narratives roundtable discussion, during the First International Seminar - History of the Present Time, promoted by the Graduate Program in History of UDESC and ANPUH- Santa Catarina, held on November 7-9, 201, in Florianópolis/SC. It problematizes the subject and its speech, the testimony becomes clear as a narrative and the many possible ways in which the traumatic experience results in narratives of self.

Keywords: Narratives of self. Traumatic memories. History of the present time.

\section{Referências}

AA.VV. Nosotras, presas políticas 1974-1983. Buenos Aires: Nuestra América, 2006.

ACTIS, M. y otras. Ese infierno. Buenos Aires: Altamira, 2006.

ARFUCH, L. El espacio biográfico. Dilemas de la subjetividad contemporánea. Buenos Aires: Fondo de Cultura Económica, 2002.

------ La entrevista, una invención dialógica. (2da. Edición). Buenos Aires: Paidós, 2010.

BAJTIN, M. Estética de la creación verbal, Mexico: Siglo XXI, 1982 [1979].

BENVENISTE, E. Problemas de lingüística general. México: Siglo XXI, 1983 (1971) [1966].

BONASSO, M. Recuerdo de la muerte, México: Ediciones Era, 1984.

CIOLLARO, N. Pájaros sin luz, Testimonios de mujeres de desaparecidos. Buenos Aires: Planeta, 1999.

DE CERTEAU, M. L'écriture de l'histoire. Paris: Gallimard, 1975.

DE LAURETIS, T. Alicia ya no. Madrid: Cátedra, 1992 [1984].

DE MAN, P. “Autobiography as De-facement” en The Rhetoric of romanticism. New York: Columbia University Press, 1984, p. 67-81.

Allegories of Reading. New Haven and London: Yale University, 1979.

DIANA, M. Mujeres guerrilleras. Sus testimonios en la militancia de los setenta. Buenos Aires: Planeta, [1996] 2006.

DIDI-HUBERMAN, G. Imágenes pese a todo. Memoria visual del holocausto. Barcelona: Paidós, 2004. 
GADAMER, H. Verdad y método. Salamanca: Sígueme, 1977 [1975].

GILMORE, L. Autobiographics. A feminist theory of women's self-representation. New York-Ithaca: Cornell University Press, 1994,

The limits of autobiography. Trauma and testimony, New York-Ithaca:

Cornell University Press, 2001.

GREIMAS, A.J. Du Sens II. Paris : Seuil, 1983.

PROPP, V. Morfología del cuento. Madrid: Fundamentos, 1977 [1928].

RICOEUR, P. Temps et récit. Tomos I, II y III. Paris : Seuil, 1984, 1985.

ROMANO SUED, S. Procedimiento. Memoria de La Perla y La Ribera. Cordoba: El Emporio Ediciones, 2007.

WHITE, H. El contenido de la forma. Barcelona: Paidós, 1992 [1987].

Prometeo, 2010.

Ficción histórica, historia ficcional y realidad histórica. Buenos Aires: 